\title{
The cognitive behavioral therapy causes an improvement in quality of life in patients with chronic musculoskeletal pain
}

\author{
A terapia cognitiva-comportamental causa melhora na qualidade de vida em pacientes \\ com dor crônica musculoesquelética
}

Martha M. C. Castro ${ }^{1,2}$, Carla Daltro', Durval Campos Kraychete', Josiane Lopes ${ }^{1}$

\begin{abstract}
Chronic pain causes functional incapacity and compromises an individual's affective, social, and economic life. Objective: To study the cognitive behavioral therapy (CBT) effectiveness in a group of patients with chronic pain. Methods: A randomized clinical trial with two parallel groups comprising 93 patients with chronic pain was carried out. Forty-eight patients were submitted to CBT and 45 continued the standard treatment. The visual analogue, hospital anxiety and depression, and quality of life SF-36 scales were applied. Patients were evaluated before and after ten weeks of treatment. Results: When the Control Group and CBT were compared, the latter presented reduction of depressive symptoms ( $p=0.031)$ and improvement in the domains 'physical limitations' ( $p=0.012)$, 'general state of health' ( $p=0.045)$, and 'limitations by emotional aspects' ( $p=0.025)$. Conclusions: The CBT was effective and it has caused an improvement in more domains of quality of life when compared to the Control Group, after ten weeks of treatment.
\end{abstract}

Key words: chronic pain, depression, anxiety, cognitive behavioral therapy.

\section{RESUMO}

Dor crônica provoca incapacidade funcional e compromete a vida afetiva, social e econômica de um sujeito. Objetivo: Estudar a eficácia da terapia cognitiva-comportamental (TCC) em um grupo de pacientes com dor crônica. Métodos: Um ensaio clínico randomizado com dois grupos paralelos de 93 pacientes foi realizado. Destes, 48 foram submetidos à TCC e 45 continuaram o tratamento padrão. Foram aplicadas as escalas visual analógica de dor, hospitalar de ansiedade e depressão e de qualidade de vida SF-36 antes e após dez semanas do tratamento. Resultados: Ao comparar o Grupo Controle e a TCC, o último apresentou redução dos sintomas depressivos ( $p=0,031)$, melhora nos domínios 'Limitações físicas' ( $p=0,012)$, 'estado geral de saúde’ ( $p=0,045)$ e 'limitações por aspectos emocionais' ( $p=0,025)$. Conclusões: A TCC foi eficaz e causou mais melhora nos domínios da qualidade de vida, quando comparada com o Grupo Controle, após dez semanas de tratamento.

Palavras-Chave: dor crônica, depressão, ansiedade, terapia cognitivo-comportamental.

Chronic pain, from its subjective nature, can be understood in different ways by each individual, according to age group, gender, cultural context, and previous experiences ${ }^{1}$. Besides, patients with chronic diseases, who need continuous treatment for a long period, present important changes of humor and in their quality of life. Some authors suggest that the greater the intensity of pain, the lower the perception of the individual's control about his/her life. This is mainly related to social damages, changes in the activities of daily life, sleep and appetite, among others ${ }^{2,3}$.

Chronic pain treatment is multimodal and includes using several drugs or physical interventions, besides psychotherapy ${ }^{4}$. The cognitive behavioral therapy (CBT) aims at helping patients to be able to evaluate the impact of pain on their lives, encouraging them to keep the orientation to solve problems and to develop means of learning how to deal with pain chronicity ${ }^{5}$. Thus, patients recognize the relation between cognition responses, humor and behavior and then they develop more adaptive responses in their daily lives ${ }^{6}$.

The CBT considers that the cognitive processes are involved in the cause of distortions and dysfunctional behaviors facing several possibilities of interpretation of reality, which can compromise the individual's biopsychosocial health. In chronic painful cases, many times, there is no more observable injury or it is disproportionate

\footnotetext{
Centro de Dor do Complexo Universitário Professor Edgard Santos, Universidade Federal da Bahia (UFBA), Salvador BA, Brazil.

${ }^{1}$ Universidade Federal da Bahia (UFBA), Salvador BA, Brazil;

${ }^{2}$ Escola Bahiana de Medicina e Saúde Pública, Salvador BA, Brazil.

Correspondence: Martha Castro;Avenida Professor Magalhães Neto 1.541 / sala 304; 41810-011 Salvador BA - Brasil; E-mail:marthamcastro@uol.com.br Conflict of interest: There is no conflict of interest to declare.

Received 29 June 2012; Received in final form 19 July 2012; Accepted 26 July 2012
} 
to the complaint about incapacity or suffering. In this case, psychosocial aspects influence the way patients realize, express, and how they deal with their pain. Hence, the CBT is important to help patients identifying thoughts, attitudes, beliefs, and behaviors ${ }^{7}$.

The beliefs that chronic pain results in poor adaptation of the individual and the evidences that CBT improves cognitive, social, and behavioral aspects have taken many authors to study the effect of this therapy in this group of patients with chronic musculoskeletal pain ${ }^{8,9}$.

The objective of this study was to test the effectiveness of CBT in patients with chronic musculoskeletal pain as for intensity of pain, presence of anxiety and depressive symptoms, and quality of life.

\section{METHODS}

It was a randomized clinical trial with parallel groups. From a group of 400 patients, who were cared for in the Clinic of Pain of Professor Edgar Santos University Complex, individuals with no mental disease were selected, according to the assessment of a brief mini-plus structured diagnostic interview compatible with the diagnostic criteria from Diagnostic and Statistical Manual of Mental Disorders ${ }^{10,11}$.

The inclusion criteria were patients with musculoskeletal pain diagnostic for at least three months, and those under medication treatment (anti-inflammatory and muscle relaxant in their usual doses), according to protocols. Exclusion criteria included patients with chronic pain of oncological or neuropathic origin, or mixed (nociceptive and neuropathic pain including fibromyalgia); use of antidepressant or other drugs that act at the central nervous system; and being disabled to write. The diagnoses were made by two pain specialists according to the International Association for the Study of Pain (IASP) criteria ${ }^{12}$. Ninety-three patients were selected to compose the samples (Figure). It was considered as a primary endpoint the reduction of the intensity of pain in $25 \%$, which was evaluated according to the visual analogue scale (VAS) scale, and as a secondary endpoint the improvement of anxiety and depressive symptoms and of the quality of life scores. Each patient was designated by a growing number, according to the time he/she started his/her participation in the study and then they were disposed in two groups at random. The list of patients was organized by an independent subject, who had no relation to the treatment or evaluation. The randomization was done with the help of a statistical program (SPSS 11.0).

Sociodemographic variables, such as gender, age, marital status, and occupation, were studied. Intensity of pain was investigated through $\mathrm{VAS}^{13}$ and the period of time patient had pain was also evaluated. Anxiety and depressive symptoms were assessed through the Hospital Anxiety and Depression Scale (HADS) ${ }^{14}$, and quality of life was measured by the Quality of Life Scale (SF-36) ${ }^{15}$.

The data collection occurred between August 2007 and December 2008. After the informed consent was signed, patients were submitted to two-hour sessions of CBT per week, for ten weeks. The evaluations occurred before and after these ten weeks of therapy.

\section{Calculating the sample size}

To have a power of $75 \%$ and a $5 \%$ of significance level, it was necessary to include 48 patients in each group to respond the research question.

\section{Statistical analysis}

The results of continuous variables were presented as mean and standard deviation or median and interquartile interval, according to the distribution of the variable. The normality criterion was based on Kolmogorov-Smirnov's test for normality. Categorical variables were expressed as proportions. In order to test the association between categorical variables, it was used the $\chi^{2}$ or Fisher's exact tests. To compare the continuous variables in

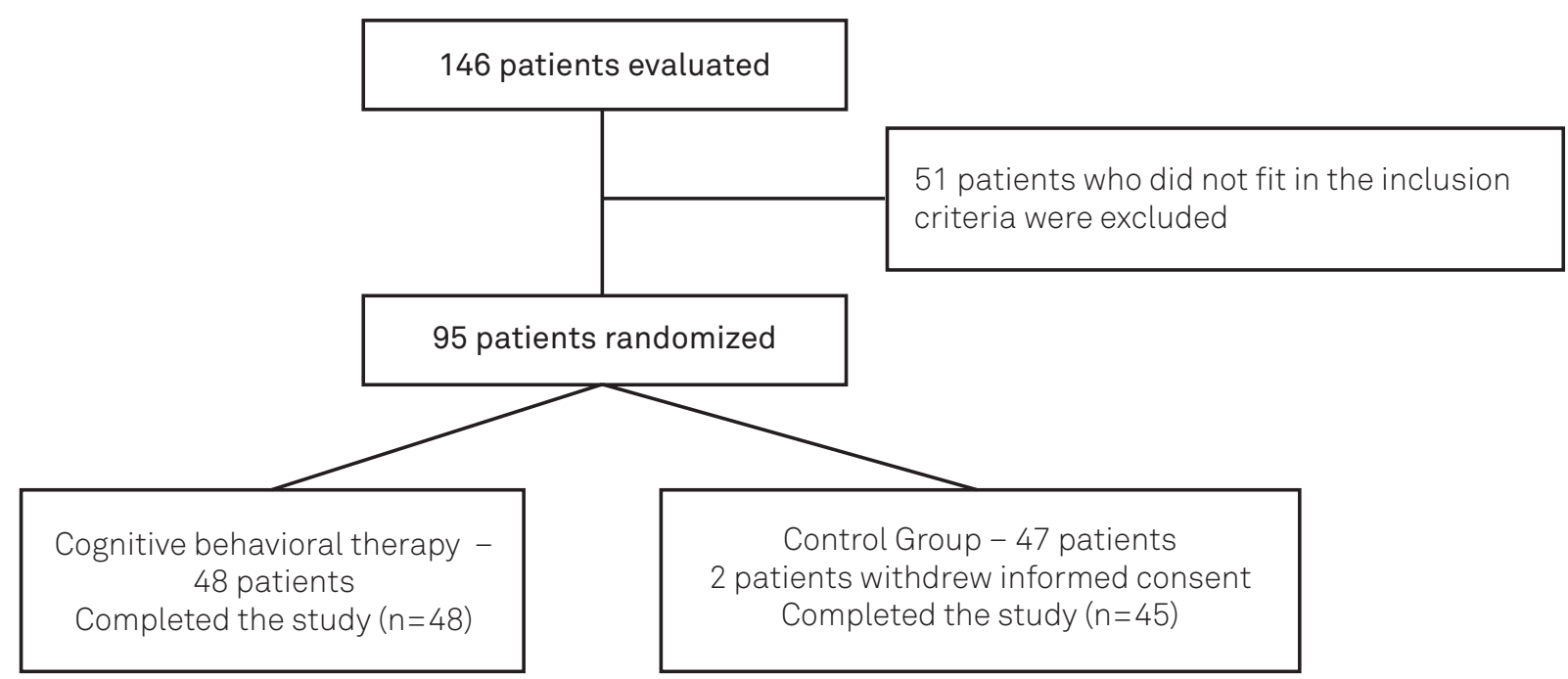

Figure. Randomized clinical trial with two parallel groups. 
both groups, the Student's $t$ or Mann-Whitney's tests were applied for independent samples. The association measures used were the relative risk (RR) and its 95\% confidence interval (95\%CI). Values minor or equal to 0.05 ( $\mathrm{p} \leq 0.05)$ were considered significant. This project was approved by the local ethics committee.

\section{RESULTS}

Forty-eight patients were evaluated in the group treated with CBT and 45 in the Control Group. Table 1 presents information related to age, gender, marital status, occupation, and the period patients had pain.

Table 2 shows the comparison of treated groups with regard to the intensity of pain, anxiety and depressive symptoms, and quality of life, which were evaluated before and after the intervention. Before the intervention, groups did not present a

Table 1. Sociodemographic data and period of time with pain before the intervention.

\begin{tabular}{|c|c|c|c|}
\hline Characteristics & $\mathrm{CBT}, \mathrm{n}=48(\%)$ & $\begin{array}{c}\text { Control Group, } \\
n=45(\%)\end{array}$ & $p$-value \\
\hline Age* & $45.9(8.1)$ & $48.7(14.3)$ & 0.255 \\
\hline Gender - female & $48.0(100.0)$ & $35.0(77.8)$ & 0.002 \\
\hline \multicolumn{4}{|l|}{ Marital status } \\
\hline With partner & $28.0(58.3)$ & $26.0(57.8)$ & \multirow[t]{3}{*}{0.957} \\
\hline Without partner & $20.0(41.7)$ & $19.0(42.2)$ & \\
\hline Occupation & & & \\
\hline \multirow{2}{*}{$\begin{array}{l}\text { Without occupation } \\
\text { Acting }\end{array}$} & $37.0(77.1)$ & $42.0(93.4)$ & \multirow[t]{2}{*}{0.04} \\
\hline & $11.0(22.9)$ & $3.0(6.7)$ & \\
\hline \multicolumn{4}{|l|}{$\begin{array}{l}\text { Period of time with } \\
\text { pain }\end{array}$} \\
\hline Until 2 years & $3.0(6.3)$ & $9.0(20.0)$ & \multirow{4}{*}{0.228} \\
\hline 2 to 5 years & $16.0(33.3)$ & $15.0(33.3)$ & \\
\hline 5 to 10 years & $11.0(22.9)$ & $7.0(15.6)$ & \\
\hline$>10$ years & $18.0(37.5)$ & $14.0(31.1)$ & \\
\hline
\end{tabular}

Table 3. Comparison of treated groups with regard to intensity of pain, anxiety and depressive symptoms, and quality of life, evaluated after the intervention.

\begin{tabular}{|c|c|c|c|}
\hline \multirow{2}{*}{ Characteristics } & \multicolumn{3}{|c|}{10 weeks after the intervention } \\
\hline & CBT $(n=48)$ & Control Group $(n=45)$ & $p$-value \\
\hline VAS & $5.7 \pm 1.7$ & $5.3 \pm 1.1$ & 0.090 \\
\hline \multicolumn{4}{|l|}{ HADS } \\
\hline Anxiety & $28.0(58.3 \%)$ & $32.0(71.1 \%)$ & 0.198 \\
\hline Depression & $17.0(35.4 \%)$ & $26.0(57.8 \%)$ & 0.031 \\
\hline \multicolumn{4}{|l|}{ SF-36 } \\
\hline Functional capacity & $36.7 \pm 20.4$ & $32.9 \pm 18.7$ & 0.457 \\
\hline Physical limitations & $22.4 \pm 20.1$ & $13.5 \pm 19.0$ & 0.012 \\
\hline Pain & $33.8 \pm 16.0$ & $33.1 \pm 18.1$ & 0.935 \\
\hline $\begin{array}{l}\text { General } \\
\text { state of health }\end{array}$ & $42.2 \pm 21.8$ & $33.1 \pm 18.2$ & 0.045 \\
\hline Vitality & $35.0 \pm 19.9$ & $28.2 \pm 18.5$ & 0.091 \\
\hline Social aspects & $50.0 \pm 22.8$ & $44.7 \pm 18.1$ & 0.224 \\
\hline Emotional limitations & $31.8 \pm 30.1$ & $20.7 \pm 29.3$ & 0.025 \\
\hline Mental health & $49.2 \pm 19.5$ & $44.2 \pm 21.2$ & 0.216 \\
\hline
\end{tabular}

significant statistically difference, except in domain pain, which has shown lower scores in the CBT Group (0.034). When both groups were compared after ten weeks of treatment, it was observed that in the group submitted to CBT, 25 ones (54\%) presented a reduction in pain greater than or equal to $25 \%$, while in the Control Group this happened only with 13 patients (28.9\%), $\mathrm{RR}=1.88$; 95\%CI 1.11-3.19). There was no reduction of anxiety symptoms. However, in the group treated with CBT, there was a reduction of depressive symptoms ( $p=0.03$ ). As to quality of life, physical limitations measures, general state of health, and emotional limitations, patients submitted to CBT had better results than the ones in the Control Group (Table 3).

Table 2. Comparison of treated groups with regard to intensity of pain, anxiety and depressive symptoms, and quality of life, evaluated before the intervention.

\begin{tabular}{|c|c|c|c|}
\hline \multirow[b]{2}{*}{ Characteristics } & \multicolumn{3}{|c|}{ Before the intervention } \\
\hline & $\begin{array}{c}\text { CBT } \\
(n=48)\end{array}$ & $\begin{array}{l}\text { Control } \\
\text { Group } \\
(n=45)\end{array}$ & $p$-value \\
\hline VAS & $6.92 \pm 2.11$ & $6.38 \pm 1.75$ & 0.185 \\
\hline \multicolumn{4}{|l|}{ HADS } \\
\hline Anxiety & $40.0(83.3 \%)$ & $37.0(82.2 \%)$ & 0.887 \\
\hline Depression & $33.0(68.8 \%)$ & $30.0(66.6 \%)$ & 0.830 \\
\hline \multicolumn{4}{|l|}{ SF-36 } \\
\hline $\begin{array}{l}\text { Functional } \\
\text { capacity }\end{array}$ & $28.6 \pm 15.0$ & $28.8 \pm 22.1$ & 0.336 \\
\hline $\begin{array}{l}\text { Physical } \\
\text { limitations }\end{array}$ & $14.6 \pm 24.9$ & $11.9 \pm 21.2$ & 0.497 \\
\hline Pain & $25.1 \pm 16.0$ & $32.3 \pm 16.5$ & 0.034 \\
\hline $\begin{array}{l}\text { General state of } \\
\text { health }\end{array}$ & $36.0 \pm 19.6$ & $30.0 \pm 16.1$ & 0.244 \\
\hline Vitality & $29.9 \pm 19.8$ & $28.1 \pm 17.3$ & 0.754 \\
\hline Social aspects & $39.5 \pm 21.0$ & $36.7 \pm 21.4$ & 0.552 \\
\hline $\begin{array}{l}\text { Emotional } \\
\text { limitations }\end{array}$ & $22.0 \pm 28.9$ & $12.2 \pm 23.6$ & 0.059 \\
\hline Mental health & $43.0 \pm 20.0$ & $40.3 \pm 19.9$ & 0.514 \\
\hline
\end{tabular}




\section{DISCUSSION}

This study concluded that CBT in group was able to reduce intensity of pain, depressive symptoms and to improve quality of life in the following domains: general state of health, physical and emotional limitations in patients with chronic musculoskeletal pain.

The group submitted to CBT also presented higher reduction in the intensity of pain, if compared to the Control one. Another study, which aimed at evaluating the result of VAS in 211 patients and that had a variation according to the type of treatment (CBT, physical treatment - PT, and $\mathrm{CBT}+\mathrm{PT}$ ), showed no differences in the intensity of pain in the studied groups ${ }^{16}$.

Other clinical trials have demonstrated that CBT has reduced the intensity of pain in patients with fibromyalgia ${ }^{17}$, chronic temporomandibular disorder pain ${ }^{18}$, and chronic fatigue syndrome ${ }^{19,20}$. This improvement lasted for a period from six months to one year. However, these findings may be related to the way in which the patient began to deal with pain. Patient with acute pain easily demonstrates suffering and seeks for its immediate relief, while the one who suffers from chronic pain tends to adapt him/herself to the pain, even without realizing it, since the pain becomes part of his/her daily life and of his/her family. Through the adaptation to pain, the individual is able to deal with social environment without showing intensity of pain, resulting, many times, in the uncertainty of suffering authenticity.

The chronic illness, the necessity of continuous treatment and the presence of comorbidities are relevant factors to determine the population's quality of life. In this study, some domains related to SF-36 increased in the CBT Group, comparing to the Control one. This is also the conclusion of a study that used the same quality of life scale in chronic patients and obtained the lowest results in the items physical limitations and vitality ${ }^{21}$. However, the results are still below the expected average, confirming some studies that have used this scale and demonstrated that patients with chronic pain present low quality of life ${ }^{22-24}$.

The fact that there was no increase in the scores of SF-36 in all items demonstrates that these patients can, from the moment the intervention is done, learn how to deal with everyday life in more adaptive ways. Therefore, the general state of health improves. The increase of the items related to physical and emotional limitation may have happened from the learning of techniques as assertive behavior, relaxation, training in problem solving, and self-control.

The anxious reactions generally increase when painful situations appear, together with fear and insecurity in facing an unknown diagnosis. However, when the cause of painful phenomenon is not overcome, and it becomes a chronic process, feelings of hopelessness, impotence, and despair can turn into other depressive symptoms or the depression itself ${ }^{25-26}$.

In this study, we observed an improvement in depressive symptoms in the group undergoing CBT. Similar outcome was reported by McCracken et al. ${ }^{23}$, who studied the effectiveness of CBT in highly disabled individuals with chronic pain. They showed an improvement after treatment in painrelated distress, disability, depression, pain-related anxiety, daytime rest, and performance during an activity tolerance test. Depressive symptoms can be reduced probably as a result of relaxing and self-control techniques emphasized in most of sessions of therapy ${ }^{27}$.

The limitations of this study refer to the short duration of follow-up, which do not allow testing the effectiveness of CBT in a longer period of time.

Thus, after a ten-week period of treatment the CBT in group presented effectiveness in the pain treatment of patients with chronic musculoskeletal pain, and there was a significant improvement of depressive symptoms and of some domains of the quality of life scale (SF-36).

From the results of this study, it is evident the necessity of investigating carefully the population who suffers from chronic pain concerning depression, anxiety, and quality of life.

\section{References}

1. Ciaramella A, Grosso S, Poli P, et al. When pain is not fully explained by organic lesion: a psychiatric perspective on chronic pain patients. Eur J Pain 2004;8:13-22.

2. Masheb RM, Kerns RD, Lozano C, Minkin MJ, Richman S. A randomized clinical trial for women with vulvodynia: cognitive-behavioral therapy vs. supportive psychotherapy. Pain 2009;141:31-40.

3. Morley S, Eccleston C, Williams A. Systematic review and metaanalyses of randomized controlled trials of cognitive behavior therapy and behavior therapy for chronic pain in adults excluding headache. Pain 1999;80:1-13.

4. Oliveira AS, Bermudez CC, Souza RA, Souza CM, Dias EM, Castro CE. Pain impact on life of patients with temporomandibular disorder. J Appl Oral Sci 2003;11:138-143.

5. Sakata RK, Issy AM. Dor: guia de medicina ambulatorial e hospitalar. São Paulo, SP: Manole; 2003.
6. Williams DA, Cary MA, Groner KH, et al. Improving physical functional status in patients with fibromyalgia: a brief cognitive behavioral intervention. J Rheumathol 2002;29:1280-1286.

7. Pimenta CAM. Dor: manual clínico de enfermagem. São Paulo, SP: [s.n.]; 2000.

8. Bruch A, Rosa JL, Leopoldo AC, et al. Relação de distúrbios mentais em uma população com doenças musculoesqueléticas ou reumatológicas. Rev Dor 2006;7:875-881.

9. Redondo JR, Justo CM, Moraleda FV, et al. Long-term efficacy of therapy in Patient with fibromyalgia: a physical exercise-based program and a cognitive-Behavioral approach. Arthritis Rheum 2004;51:184-192.

10. Lecrubier $\mathrm{Y}$, Sheehan DV, Weiller E, et al. The Mini International Neuropsychiatric Interview (MINI), a short diagnostic structured interview: reliability and validity according to the CIDI. Eur Psychiatry 1997;12:224-231. 
11. Amorim P. Mini International Neuropsychiatric Interview (MINI): validação de entrevista breve para diagnóstico de transtornos mentais. Rev Bras Psiquiatr 2000;22:106-115.

12. Huskisson EC. Measurement of pain. Lancet 1974;2:1127-1131.

13. Pimenta CA. Conceitos culturais e a experiência dolorosa. Rev Escola Enf USP 1998;32:179-186.

14. Botega NJ, Pondé MP, Medeiros P, Lima MG, Guerreiro CA. Validação da escala hospitalar de ansiedade e depressão (HAD) em pacientes epiléticos ambulatoriais. J Bras Psiq 1998;47:285-289.

15. Ciconelli RM. Tradução para o português e validação do questionário genérico de avaliação de qualidade de vida "Medical outcomes study 36-item short-form health survey (SF-36)" [thesis]. São Paulo, SP: Universidade Federal de São Paulo, Escola Paulista de Medicina; 1997.

16. Smeets RJ, Vlaeyen JW, Kester AD, Knottneru JA. Reductionof pain catastrophizing mediates the outcome of both physical and cognitivebehavioral treatment in chronic low back pain. J Pain 2006;7:261-271.

17. Oliveira AS, Bermudez CC, Souza R, et al. Impacto da dor na vida de portadores de disfunção temporomandibular. J Appl Oral Sci 2003;11:138-143.

18. Turner JA, Mancl L, Aaron LA. Short-and-long term efficacy of brief cognitivebehavioral therapy for patients with chronic temporomandibular disorder pain: a randomized controlled trial. Pain 2006;121:181-194.

19. Knoop H, Stulemeijer M, Prins J, Van der Meer JW, Bleijenberg G. Is cognitive behavior therapy for chronic fatigue syndrome also effective for pain symptons? Behav Res Ther 2007;45:2034-2043.
20. Koleck M, Mazaux JM, Rascle N, Bruchon-Schweitzer M. Psychosocial factors and coping strategies as predictors of chronic evolution and quality of life in patients with low back pain: a prospective study. Eur J Pain 2006;10:1-11.

21. Thommasen HV, Zhang W. Impact of chronic disease on quality of life in the Bella Coola Valey. Rural Remote Health 2006;6:528.

22. Dworkin SF, Turner JA, Wilson $L$ et al. Brief group cognitivebehavioral intervention for temporomandibular disorders. Pain 1994;59:175-187.

23. McCracken LM, MacKichan F, Eccleston C. Contextual cognitivebehavioral therapy for severely disabled chronic pain sufferers: effectiveness and clinically significant change. Eur $J$ Pain 2007;11:314-22.

24. King M, Davidson O, Taylor F, et al. Effectiveness of teaching general practitioners skills in brief cognitive behavior therapy to treat patients with depression: randomized controlled trial. BMJ 2002;324:947-950.

25. Matta AP, Moreira Filho PF. Sintomas depressivos e ansiedade em pacientes com cefaléia do tipo tensional crônica e episódica. Arq Neuropsiquiatr 2003;61:991-994.

26. Cunha AC, Burke TN, Franca FJ, Marques AP. Effect of global posture reeducation and of static stretching on pain, range of motion, and quality of life in women with chronic neck pain: a randomized clinical trial. Clinics 2008;63:763-770.

27. Menzel NN, Robinson ME. Back pain in direct patient care providers: early intervention with cognitive behavioral therapy. Pain Manag Nurs 2006;7:53-63. 